Faculty of Business

Faculty Publications

This is a post-print version of the following article:

Spirituality and Entrepreneurship: The Role of Magical Thinking in Future-Oriented Sensemaking, Organization Studies

Max Ganzin, Gazi Islam, and Roy Suddaby

2019

The final publication is available at:

https://doi.org/10.1177/0170840618819035

Citation for this paper:

Ganzin, M., Islam, G., \& Suddaby, R. (2019). Spirituality and Entrepreneurship: The Role of Magical Thinking in Future-Oriented Sensemaking. Organization Studies, 41(1), 77-102. https://doi.org/10.1177/0170840618819035 


\section{Spirituality and Entrepreneurship: The Role of Magical Thinking in Future- Oriented Sensemaking}

The role of spirituality in entrepreneurial cognition has drawn increasing interest among entrepreneurship scholars (e.g. Mauksch, 2017; Balog, Baker, \& Walker, 2014; Dana, 2009; Dodd \& Gotsis, 2007). Entrepreneurs engage in activities reminiscent of spirituality as they focus on deep personal commitment and meaning (Balog et al., 2014) and confront obstacles, often with scant social support from friends and family. Successful entrepreneurship requires dedicated action and commitment in the face of future uncertainty (e.g. McKelvie, Haynie \& Gustavsson, 2011; McMullen \& Shepherd, 2006), an entrepreneurial "mindset" (Balog et al., 2014) that may draw support from entrepreneurial spirituality.

Spirituality offers an explanation of how entrepreneurs persist despite seemingly insurmountable odds by extending notions of future-oriented sensemaking (Gioia \& Mehra, 1996; Gephart, Topal \& Zhang, 2010). "Prospective" and "future-oriented" sensemaking are often used as synonyms in the literature; we use the term "future-oriented" to avoid the sense of polarizing between "retrospective" and "prospective". Spirituality has been invoked to explain how "enchanted" visions of entrepreneurial futures are sustained beyond rational expectations (Mauksch, 2017). Holding fast to such visions may be crucial for entrepreneurial resilience in the wake of inevitable failures and setbacks (Cardon, Stevens \& Potter, 2011). Entrepreneurs coping with high risk and uncertainty may draw upon future-oriented sensemaking to explain to themselves how the world works, link past and future, and persuasively articulate their visions to key stakeholders (Hill \& Levenhagen, 2005; Grégoire, Corbett \& McMullen, 2011)

Prior research helps to understand how future-oriented sensemaking mitigates risks of unknown futures, by extrapolating the future from interpretations of the past (Maitlis \& Christianson, 2014). Entrepreneurs cope with doubt, risk and uncertainty by extending past 
successes into the future (Cornelissen \& Clarke, 2010); yet how future-oriented sensemaking operates in the absence of a history of individual or collective success is not well understood. How entrepreneurs are able to construct confident narratives of the future around situations that, by definition, have not happened, remains a conceptual and empirical problem. If spirituality provides an entrepreneurial resource for future-oriented sensemaking, then how does futureoriented sensemaking draw upon spirituality to mitigate risk, reduce uncertainty and inspire the confidence of external stakeholders in the absence of a rational historical context?

In this study, we examine how future-oriented sensemaking draws upon magical thinking to justify entrepreneurial activity in the context of a larger cosmological belief system. We suggest that spirituality plays a critical but largely unrecognized role in entrepreneurial cognition. Through an in-depth qualitative analysis of Canadian entrepreneurs drawn from a business incubator, we outline a form of spiritually-charged sensemaking that we term "magical realism" and which describes an orientation to future decisions that combines realism with moments of spiritual resilience in the face of risk.

Within this broader magical realist orientation, we identify and elaborate three distinct dimensions, which we term "affective-attitudinal", "cognitive-epistemic" and "pragmaticmotivational". Collectively, these three dimensions define an integrated entrepreneurial belief system based on spirituality. We invoke the term "magical realism" to circumscribe this tripartite constellation of orientations describing a specific form of entrepreneurial cognition that mixes rational and transcendent elements within a wider system of meaning and purpose. This term, originally derived from a literary and cultural movement (Zamora \& Faris, 1995), characterizes a narrative style that juxtaposes realistic depictions with the subjective perspectives of actors who see reality as pervaded by magical or spiritual forces. By elaborating the construct of magical realist thinking, we lay the groundwork for a more unified theory of spirituality in the context of entrepreneurial cognition. 
Our paper proceeds in three stages. First, we justify our research question around spirituality in the context of an emerging literature on future-oriented sensemaking in entrepreneurial cognition. Next, we present an in-depth qualitative study of entrepreneurs, describing our findings in terms of the affective-attitudinal, cognitive-epistemic and pragmaticmotivational bases of magical realism. Finally, we discuss implications for understanding spirituality in entrepreneurship and specify directions for future research.

\section{Facing the Future: Risk, Uncertainty, and Spirituality}

Entrepreneurial ventures are inherently risky and uncertain (Milliken, 1987). McMullen and Shepard (2006: 135) note that this uncertainty involves three foundational questions for entrepreneurs: (1) what is happening out there? (2) how will it affect me? and, (3) what am I going to do about it? These three questions parse entrepreneurial uncertainty into three constituent elements - uncertainty about the environment, uncertainty about its personal impact on the venture and uncertainty about how to respond.

Substantial research supports the conclusion that entrepreneurs are distinguished by how they cognitively process uncertainty (Milliken, 1987; McKelvie, Haynie \& Gustavsson, 2011). While most individuals find environmental turbulence stressful and disorienting, entrepreneurs' cognitive biases (Busenitz \& Barney, 1997) allow them to filter information differently (von Gelderen, Frese \& Thurik, 2000) and perceive environmental turbulence as opportunity rather than risk (Busenitz \& Lau, 1996; Mitchell et al., 2000; Krueger, 2003). So, for example, successful entrepreneurs tend to exhibit significantly higher levels of resilience to adversity than the general population (Gatewood et al., 2002; Baron \& Markman, 1999).

Entrepreneurs' worldviews thus allow them to see risk, uncertainty and ambiguity somewhat optimistically and, arguably, less objectively than non-entrepreneurs. While such optimism may draw on prior experience, the empirical evidence suggests that even novice entrepreneurs process perceived risk more optimistically than the general population, a 
phenomenon that Hayward, Shepherd \& Griffin (2006) term “entrepreneurial hubris". Hayward and colleagues (2006: 163) argue that entrepreneurs' optimistic world-views are driven by their particular ways of seeing the world - that their high confidence when faced with adversity 'is driven by actors' interpretation or construal of their experiences (Kruger \& Dunning, 1999; Griffin \& Ross, 1991) and is largely unaffected by the features of others (Ball et al., 1991) or the situation (Moore \& Kim, 2003)".

At the same time, we know little about the basis of this optimistic world-view construction or the processes of interpretation involved. For instance, studies of entrepreneurial sensemaking note how interpretations of past failures depend on sensemaking processes (Cardon, Stevens \& Potter, 2011), but little is known about future-oriented entrepreneurial sensemaking, where no prior data exists to ground such interpretations. Even less is known about the role spirituality plays in providing cosmological systems from which to construct such interpretations. Understanding this role can facilitate understanding of entrepreneurial activity and decision making. In essence, to understand how entrepreneurs perceive risk and uncertainty, we need to understand how they make sense of the world. Particularly, because entrepreneurial activity looks to the future, and uncertainty is, by definition, a matter of the future, we need to understand entrepreneurial sensemaking about the future.

\section{Future-oriented Sensemaking}

The foregoing discussion suggests that entrepreneurs make sense of past experiences and project that experience into the future in a different way than most "rational" individuals do. Sensemaking is the process through which individuals attempt to understand novel, ambiguous or surprising events (Weick, 1995; Maitlis \& Christianson, 2014). While early literature largely focused on retrospective qualities of sensemaking, recent research has called for a present and future-oriented focus in sensemaking (Wiebe, 2010; Colville \& Pye, 2010; 
Holt \& Cornelissen, 2014; Colville, Pye, \& Brown, 2015). Some research has even called for rethinking temporality in sensemaking altogether, to consider the interplay of prospective and retrospective aspects of sensemaking (Introna, 2018; Konlechner, Latzke, Guttel, Hofferer, 2018). Guiette and Vandenbempt (2015) argue that in times of dynamic complexity and uncertainty, "the temporal dimension of sensemaking becomes pivotal given that the past is a poor predictor of emerging futures" (p. 91). Holt and Cornelissen (2014) note that "sense [is] being governed by exposure to unknown possibility rather than retrospective assessment" ( $\mathrm{p}$. 525). This is especially true in contexts of high uncertainty (Moore \& Koning, 2015; Guiette \& Vandenbempt, 2015) such as entrepreneurial ventures (Cornelissen \& Clarke, 2010).

Future-oriented sensemaking involves active processes of reinterpreting past events to construct a coherent vision of the future (Gephart et al., 2010). For example, in their analysis of strategic change management at a U.S. university, Gioia, Thomas, Clark and Chittipeddi (1994) observe participants' repeated efforts to restructure meanings and interpretations of past events to understand the present organizational situation and project those interpretations into the future. Similarly, Stigliani and Ravasi (2012), in their study of a design consulting group, demonstrate future-oriented sensemaking processes in groups, involving interrelated cycles of retrospective cognitive work, and collective envisioning of the future.

Hill and Levenhagen (1995) and Cornelissen and Clarke (2010) have theorized meaning construction as part of future-oriented sensemaking in entrepreneurial ventures. Accordingly, entrepreneurship scholars have paid attention to the role of sensemaking in projecting optimistic futures. For example, Dorado (2005) argues that sensemaking is a crucial steppingstone for (future-oriented) strategic change in conditions of uncertainty. Rae (2000) explains that entrepreneurial learning is an intertwined process of knowing, acting, and sensemaking, and that through stories, people learn whom they can and want to be in a future-oriented process of creating prospective realities. Other studies of future-oriented sensemaking 
reinforce an obvious similarity with entrepreneurial cognition in which individuals systematically reconstruct the past to create optimistic and actionable visions of the future (Gephart et al., 2010; Lipshitz, Ron \& Popper, 2004; Cornellisen \& Clarke, 2010). Both organizations and individuals use past and present temporal orientations to project images of a stable and successful future. In doing so, they create actionable plans by describing paths, however risky, that lead to desired outcomes. However, prior research offers scant understanding of how future-oriented sensemaking might work in contexts where there is no objective past experience to draw from. Novice entrepreneurs at the start-up stage experience extremely high degrees of risk, uncertainty and ambiguity but do not have the luxury of drawing on past victories. Novice entrepreneurs likely draw upon underlying established world-views to engage in future-oriented sensemaking, yet it remains a mystery how they do so when they have no objective past to assist them.

\section{Spirituality and Magical Realism}

Spirituality offers one mechanism to understand the above process. Researchers have paid attention to spirituality in established organizations (Hicks, 2003; Rego \& Cunha, 2008; Karakas, 2010) as well as in entrepreneurial settings (Dodd \& Seaman, 1998; Dana, 2009; Balog, Baker \& Walker, 2014). We can trace the topic of spirituality to Weber ([1905] 1985), who asserted the significance of spiritual belief for the rise of modern capitalism. Arguably, entrepreneurial activity is a driving force for capitalism, and spirituality plays a significant role in entrepreneurial activity (e.g. Dana, 2009; Dodd \& Gotsis, 2007). Management and entrepreneurship scholars are beginning to tap into spirituality's influences on entrepreneurship. In a large, US-based survey, for example, Dougherty, Griebel, Neubert, and Park (2013) found a high preponderance of spiritual beliefs among entrepreneurs, with twothirds believing in a "higher power". Entrepreneurs tend to describe themselves as close to a spiritual power (Neubert, 2013). Such beliefs may be explicable in environments of high 
uncertainty and limited information, requiring a "leap of faith" to start an entrepreneurial venture (Judge \& Douglas, 2013). As Suddaby, Ganzin \& Minkus (2017) theorize, entrepreneurs often work at the boundaries of established institutions, giving rise to magical thinking as a form of "reflexive" rationality.

To support such views of entrepreneurs, psychologists and anthropologists observe that magical thinking and spirituality proliferate in situations of high risk or unstable environments, as a reaction to perceptions of diminished control (Keinan, 1994; Fisher, 1986). Entrepreneurship scholars note that spirituality provides a strong frame of reference for decision-making and influences responsible business behavior (La Pira \& Gillin, 2006; Fernando and Jackson, 2006). Spiritual capital, "the set of personal, intangible, and transcendent resources," supports business innovation and performance (Neubert, Bradley, Ardianti, \& Simiyu, 2017: 622), while spiritually-oriented entrepreneurs approach their work and life with greater joy (Kauanui, Thomas, Rubens, \& Sherman, 2010). Balog and colleagues (2014) observe that entrepreneurship is linked to spirituality though a focus on internal values, while Dana (2009) observes that spirituality-related values encourage entrepreneurship. At the interpersonal level, Dodd and Gotsis (2007) propose that spirituality enhances cooperation and trust within entrepreneurial processes, while Godwin, Neck, and D'Intino (2016) argue that spirituality provides a foundation for shaping entrepreneurial values and cognitions. Because understanding entrepreneurial cognitions is extremely important (Krueger, 2003; Baron, 2004), the link with spirituality is useful because "spirituality can inform and influence the cognition and therefore the behaviors of entrepreneurs" (Godwin et al., 2016: 66). In short, an emergent literature in entrepreneurship has built upon the intuition that spirituality has a role to play in entrepreneurial processes.

Despite all the important findings, however, we still know little about the role of spirituality in entrepreneurial sensemaking. Spirituality is important because any sensemaking 
process constructs events as meaningful on the basis of beliefs that people possess (Sandberg \& Tsoukas, 2015: 9). Spirituality involves cognitive processes that bears a high degree of overlap with sensemaking theory. A critical trigger for sensemaking, for example, is the experience of a "cosmology episode" or the sudden loss of meaning and coherence experienced in the face of a catastrophic event (Weick, 1993). Cosmology involves adherence to a transcendent belief system involving often fatalistic assumptions of order and rationality in the universe and existing beyond individual interests. Cosmology episodes relate to spirituality in that unusual or seemingly supernatural events can challenge fundamental understandings of the universe and one's place in it.

A cosmology episode occurs "when people suddenly and deeply feel that the universe is no longer a rational, orderly system" (Weick, 1993: 633). As Orton and O’Grady (2016: 227) observe, the questions individuals ask in the face of cosmology episodes - what is the nature of the universe, what is my role in it, how am I to respond to this event - "directs explicit attention to the integral role of spirituality during catastrophic events" and bear a striking similarity to the fundamental questions faced by entrepreneurs. Although researchers have looked into the connection between spirituality and sensemaking (McKee, Mills \& Driscoll, 2008; Lips-Wiersma, 2001; Pratt, 2000), the mechanisms by which spirituality helps entrepreneurs to make sense of future-oriented uncertainty remain unknown.

Considered together, the constructs of spirituality and magical thinking appear to offer a potentially fruitful theoretical direction in addressing our core question of how entrepreneurs are able to persist and succeed in the face of high risk, uncertainty, and ambiguity. We see value in emphasizing the importance of how spiritual belief and the magical thinking that emerges from such belief can constitute an "ideological fortress" by which entrepreneurs make sense of their unpredictable world and find both direction and motivation (Pratt, 2000). In the absence of past empirical experience or social support and in the face of future 
uncertainty and high risk, it seems reasonable to propose that entrepreneurs find the motivation to persevere through their adherence to a larger cosmological belief system that allows them to interpret reality in a way that deviates in important respects from traditional views of objective reality or rationally scientific notions of causality and human agency.

\section{Methods}

Our research design adopted a constructivist-interpretivist perspective to examine how spirituality supports future-oriented sensemaking. This approach focuses on "understanding the complex world of lived experience from the point of view of those who live it" (Schwandt, 1994: 221). More specifically, we employ the life-story interview technique, involving reflective stories expressing how individuals interpret, reconstruct and make sense of their life histories (Atkinson, 1998, MacLean \& Pasupathi, 2011). Narratives are a critical elements of sensemaking because reflecting on past experience and infusing it with causal meaning encourages informants to make sense of change, to justify decisions and to locate one's sense of agency in time, space and context (Weick, 1995). As such, biographical narratives are not simply storehouses of information, but give insights into individual cognition (Johansson, 2004). Sensemaking, thus, is essentially a narrative process (Meyers, 2013; Brown, Stacey \& Nandhakumar, 2008).

Life story interviews have largely been used to analyze sensemaking processes in career studies (Hoyer \& Steyaert, 2015; Rouleau \& Balogun, 2011). However, life-story interviews have also been used to study entrepreneurial learning (Rae, 2000; Rae \& Carswell, 2001), foundings (Rasmussen \& Koed Madson, \& Evangelista, 2001) and decision making (Hytti, 2005). The method is particularly useful in analyzing entrepreneurial cognition and sensemaking because it focuses attention of both the researcher and the respondent on perceptions, intentions and belief structures, each of which have been identified as critical but largely unexamined elements of entrepreneurial behaviour (Krueger, 2003). 


\section{Data Collection}

We followed a strategy of purposeful or theoretical sampling (Eisenhardt, 1989; Miles \& Huberman, 1994) in selecting our informants. We initially chose informants from a business incubator that offers expertise, resources and support to entrepreneurs in Edmonton, Canada, a large city with a vibrant entrepreneurial culture. Our choice of Edmonton reflects its status as an entrepreneurial hub, located within the highest per-capita investment province in Canada, itself ranked second in terms of ease of starting a business, according to the World Bank (Economy Rankings, n.d.). The business incubator we contacted reflects the entrepreneurial landscape of the city, and is at the forefront of entrepreneurial action in the local community. We received permission from the incubator to contact entrepreneurs through a list of "graduates" of their program. Our initial selection involved identifying informants who would be most able to address our main research objective of understanding how spirituality informs entrepreneurial attitudes to risk. Then we used social media to gather a virtual snowball sampling (Baltar \& Brunet, 2012) identifying other entrepreneurs who could also address our research objective.

Approximately thirty percent of initial invitations were accepted and forty percent of accepted invitations generated an interview. We selected entrepreneurs with over five years of successful business operation to ensure sufficient practical experience, consistent with prior research on entrepreneurs (Brüderl, Preisendörfer \& Ziegler, 1992). We also only included entrepreneurs in leadership positions in their organizations, excluding self-employed individuals, consultants and other small professional organizations (i.e. lawyers, dentists etc.). In order to understand the role of spirituality, but not restricted to religion, we selected both religious and non-religious participants; specific beliefs were not a criterion, however, for inclusion or exclusion, and our coding for magical realism, described below, cut across belief systems. Although Edmonton has a predominantly Christian, Protestant population, we also 
found manifestations of other traditions. For example, entrepreneurs often talked about karma or the Universe. Ultimately, our sample consisted of forty narrative interviews with entrepreneurs from a diverse range of industry sectors. Their demographic and biographical details are set out in Table 1.

Insert Table 1 about here

Upon receiving agreement to participate in the study, we contacted each entrepreneur to arrange the date, time, and location for the interview, arranging face-to-face meetings wherever possible. Participants were provided with informed consent forms, and assured of their anonymity throughout the process. Interviews lasted between 30 to 90 minutes, with a total of 1,961 minutes of recorded interviews, yielding 570 single spaced pages of transcribed documents.

During the interviews, we asked entrepreneurs about the inception of their business and decisions leading to their venture, including challenges, and the reasons for successes or failures. Focusing on their plans for the future, we asked about their dreams and plans regarding their businesses and where they would take their activities in the future. We also asked them to compare their current explanations for success and failure to how they understood these during the time when the events took place. Thus, although many of these individuals had been entrepreneurs for some time, their narratives focused largely on their beliefs as nascent entrepreneurs. We were particularly attentive to aspects of their responses that spoke to aspects of magical, superstitious or transcendental themes, which appeared in the discourses of both religious and non-religious entrepreneurs, as detailed below. While we asked very generally about their self-identification as spiritual, we focused more in the interviews on the extent to which the entrepreneurs would attribute their success to events that were transcendental, 
magical, spiritual or pertaining to luck. By combining the prospective account of the future plans and the retrospective account of how the respondents deemed their future success as they started the business, we try to capture a cosmological orientation of entrepreneurs that helps them to make sense of the future on an ongoing basis. In short, given that entrepreneurs' spirituality may lead them to hold non-linear conception of time; for some respondents, the present seemed to contain future beliefs, and we explored how future-orientation is ingrained in the entrepreneurs' cosmology. Our inquiry thus echoes some calls to consider all dimensions of temporality (Sandberg \& Tsoukas, 2015; Holt \& Cornelissen, 2014; Colville et al., 2015) and to problematize the division of duration into past, present, and future (Introna, 2018; Bergson, 2002), remembering that "human way of being ... is to be always ahead of ourselves" (Heidegger, 1962, cited in Introna, 2018: 7).

Through the interview process, participants reflected on their experiences, and although the researchers allowed the narratives to be directed by the entrepreneurs, the call to reflect on their plans and dreams made the resulting narratives, to some extent, co-constructed (Riessman, 1993; Clandinin, 2013). Several entrepreneurs told us that they valued the interview session because it allowed them to rethink their experience and what it meant to them. They also thanked us for asking questions that helped them to reflect upon their careers and lives. Some of the sessions were quite profound and almost therapeutic because the respondents shared with us very personal stories and emotions that they rarely share with others.

\section{Data Analysis}

We analyzed narratives or stories of entrepreneurs (Riessman, 1993) abductively, with constant comparison between new data and emergent theoretical categories (Glaser \& Strauss, 1967; Lincoln \& Guba, 1985). Given our interest in spirituality as a support for entrepreneurial sensemaking narrative, we used thematic narrative analysis to explore the content and key themes common to the entrepreneurial stories (e.g. Maitlis, 2012). According to Riessman 
(2005: 3), "The thematic approach is useful for theorizing across a number of cases - finding common thematic elements across research participants and the events they report." Thematic analysis is used to explore core dimensions around which meanings are constructed (Maitlis, 2012), and fits with an abductive approach because it can draw on existing theoretical concepts during the elaboration of emerging themes (Maitlis, 2012).

Beginning with our overarching concern with spirituality, we coded for themes using a pattern analysis (Patton, 2014) to uncover commonalities in the stories told by the entrepreneurs. Pattern analysis is a process of searching for patterns in a narrative or set of narratives. Pattern refers to a descriptive finding; and the interpretation of meaning of such findings leads to the identification of themes (Patton, 2014: 541). Thematic narrative analysis involves constant comparison between the narratives to decipher themes contained and allows comparison across a body of narratives (Maitlis, 2012).

Early in our coding, the spiritual themes found seemed to group around a general orientation that we labeled "magical realism", because of its' seeming parallel to magical elements noted in literary narrative (Carpentier, 1949; Flores, 1955). The "magical realist" narrative has been described as a "way of seeing in which there is space for the invisible forces that move the world: dreams, legends, myths, emotion, passion, history" (Allende, 1991: 54). We were inspired by this description of literary narrative, and further noted that magical realism allowed us to treat spirituality concepts across both religious and non-religious respondents, an important parallel between magical realist literature and our own data. More specifically, we juxtaposed the magical narrative element with the descriptions of everyday economic reality. In our attempt to explain this paradox, we discovered the appropriateness of magical realism framework as a description of entrepreneurial cosmology. Thus, we borrowed this term that explains the oxymoronic nature of entrepreneurial cognitive orientation and focused our coding on the different themes within the magical realist entrepreneurial narrative that could function 
as mechanisms to explain entrepreneurial sensemaking. These inductively generated mechanisms were then theoretically grouped to present an overall picture of magical realist sensemaking by entrepreneurs.

Specifically, our coding suggested three sets of themes that contained "magical" thinking in different modalities. The first involved themes related to affective and attitudinal aspects such as a sense of unexplainable intuition, or the feeling of being embedded in a cosmic whole. The second theme described epistemic and cognitive issues related to finding answers and having access to esoteric or mystical knowledge. The third theme centered on magical action, involving the sense of following a transcendental law or being a vehicle for a larger force. After the emergence of these aggregate themes, we theorized the magical realist style of sensemaking as an integrated complex of these attitudinal, epistemic and pragmatic elements, which we elaborate below. Figure 1 presents our coding structure, showing the subsequent levels of abstraction, from first-order codes to aggregate themes and the overarching magical realist construct.

Insert Figure 1 about here

\section{Results}

Our analysis revealed three distinct cognitive orientations in our sample of entrepreneurs, each of which we detail in this section. The three orientations the three entrepreneurial dilemmas originally posed by McMullen and Shepherd (2006) to capture the unique existential issues faced by all entrepreneurs.

The first, which we term an affective-attitudinal orientation, addresses the issue of "what is happening out there?" by suggesting that entrepreneurs creatively reinterpret the risk and uncertainty of their external environment with an affective orientation of calm acceptance 
of the chaotic mystery of the universe paired with a confident conviction of the correctness of their worldview. This orientation requires a somewhat paradoxical combination of ceding authority, somewhat fatalistically to a higher power beyond individual control while retaining the agentic assumption that by "doing the right thing" all will be well. The second, which we call a cognitive-epistemic orientation, addresses the issue of "how will it affect me" through the entrepreneurs trusting assumption that ultimately a plan for action will be revealed to them and, by unlocking that knowledge, they will aspire to even greater success. This orientation combines both fatalism, in the form of supernatural guidance, and agency, in the inspiration and motivation that receiving that guidance will provide. By "obtaining the answers" the secrets of the universe will be revealed and provide inspiration to action. The third, termed pragmaticmotivational orientation, addresses the issue of "what am I to do", relies on the entrepreneur's intuition and higher purpose to motivate successful action in pursuit of goals. This orientation emphasizes agency, but agency inspired by both a sense of calling and an intuitive belief that the entrepreneur has finally "found his or her true path". Collectively, these orientations combine to capture a magical-realist worldview as they each integrate somewhat paradoxical themes of belief in fatalism and agency, past and future, and science and magic.

\section{Affective-Attitudinal Orientation: Being at Peace}

We used the term "Being at Peace" to describe how entrepreneurs find peace and calm in a volatile world of startup enterprises. It reflects a general attitude to going about often very risky business endeavors, maintaining an affectively calm demeanor and often treating the sense of peace with supernatural reverence. Some described being led by forces to achieve higher purposes, giving them assurances of success. Some described following the laws of life or karma, and thus being blessed and having nothing to fear. The two subthemes we saw as composing this affective-attitudinal orientation were, on the one hand, a cosmological 
assumption that life involves certain laws that may be followed to ensure success, and on the other, a belief that one is engaged in doing the right thing.

The Laws of Life. A recurring theme invoked by respondents when describing the sense of being at peace involved the importance of living by certain laws of life or laws of karma. Following such laws was symbolically important because it brought about good luck or signaled appreciation for good fortune in the past. Respondents often noted that because they are continually engaged in business with a higher purpose, they feel a strong sense of peace. The stories of following the laws of life were prominent both among religious and non-religious entrepreneurs.

Entrepreneurs told us about their conviction that being kind and good is very important for their business. They shared that this understanding influenced the way they treated their employees and other stakeholders on a daily basis, and noted the blessings that come to other business people because of obedience to such laws.

For example, Mark, a very successful entrepreneur, who founded an extremely popular website and owns a few businesses, expounds on the importance of doing good for other people:

"I'm just gonna say, I'm... I am a firm believer in Karma. And, you know, whether it's volunteering, donating, whatever, I just... I do... I do believe that good things happen to good people and so, you know, we do a lot of fund raising, we do a lot of, you know, volunteer[ing] how much we can, ahm, you know, doing favors for people, that's sort of... I do believe in the end it comes back to you.

Mark states that tries to respond to every single request he receives, based on this belief. As a successful entrepreneur he reports receiving many requests, and feels personally connected to these as decisive spiritual moments.

Entrepreneurs also talked about following a particular law of life and receiving blessings for that; for instance, being honest, donating money or tithing, and keeping religious holidays. For instance, Fred told about how he with his team decided not to open on Boxing Day, the most important business day of the year for that retail business, because it fell on Sunday, which 
Fred holds as a Sabbath. Fred described a reality that was malleable, in the spirit of magical realism, where the decision to follow the law was rewarded with the best sales day on record on Monday following the Boxing Day:

"And Monday was the biggest day we have ever had by almost double." And that week surpassed any other week, and that month surpassed any other month. "And for me immediately that was just... you know, I attributed that to a spiritual blessing for doing what I believed I should have done."

Doing the Right Thing. Many of our respondents indicated a feeling that they were doing the right thing in building their businesses, linking this feeling with a higher purpose or will. The abstract idea of doing the right thing went beyond achieving success or efficiency, but imagined the business as moving in the direction willed by a higher purpose. Often such business had stated objectives of helping people, and layered more traditional, rational business process onto a bedrock sense of spirituality in the endeavor as a whole. Engaging in futureoriented sensemaking often involved the spiritual belief that they are (now) and have been (in the past) doing the right thing, but the projected future is rational, stable and assured of success.

Entrepreneurs talked about finding peace through their engagement in an enterprise with a higher meaning. Entrepreneur Zack told us about how he found peace during a difficult time that almost destroyed his business. His story illustrates how peace can be found not only during calm periods, but when it is needed most — in the times of turmoil and uncertainty:

"Even to the point when I was going almost having to go through bankruptcy as a business. [...] I still had the faith that if that was what the outcome of the business was going to be, I was...It would've been hard. It would've been blast to my ego.[...] But at the end of the day I knew that if that's what would have..., if that's what God's will would have been then I could have come to terms with it, right? That I would have been okay. And I knew that, at that deep down inside, I really knew that. [...] It's about - do you really have the faith to put your trust in somebody you never seen that $\mathrm{He}$ is totally going to take care of you? Even if taking care of you is the failure quote unquote of your business. And I came to the realization, that yeah, I did have that faith, if that what it was, I knew that, to be honest, I knew that I was living my life the way I should be. And if that is what it came to, than I was okay. And that brings a huge sense of comfort." 
In the above statement, Zack applies his magical realist orientation, and despite the looming devastating changes, is able to construe the future as good and peaceful. This sense of peace allowed Zack to make calm decisions and to continue operations. This story illustrates a magical realist sensemaking at work repairing disruptions in reality. The disruption (the looming bankruptcy) is real, and triggers the sensemaking mechanism, including the need to project a future. The repair, however, is magical, as the entrepreneur draws upon the affective calm from knowing his is living as he should. Most entrepreneurs told us stories of overcoming difficulties, often involving overcoming challenges through the attitude of one having done the right thing, and often backed up that attitude with a spiritual or supernatural claim.

The theme of continually being at peace reflects the affective-attitudinal mechanism of coping with risk and anxiety by bringing such spirits to bear in an otherwise chaotic world. The mingling of magic and realism provides an emotional resource for coping with challenges.

\section{Cognitive-Epistemic Orientation/Obtaining the Answers}

We termed "obtaining the answers" as an orientation to knowledge and decisions which was more "cognitive" in nature than the affective-attitudinal orientation above. Magical realism regarding complex decisions involved a continuous seeking orientation, in which entrepreneurs view inspiration as an often instantaneous insight grounding their problem solving and executive decisions. The belief in the ability to obtain answers allows the entrepreneurs to construct the future as knowable and actionable.

Inspiration. Our respondents mentioned having strong impressions of needing to do something at a given moment, or receiving information directing them, sometimes attributed to supernatural forces guiding them at the right moment. For instance, the entrepreneurs mentioned inspiration during the hiring process, choices of orders to fulfill, and other strategic activities, all future-oriented. They cited past inspirations to deal with future situations, including interactions with customers or employees. Entrepreneurs may refuse, for example, to 
hire a seemingly suitable candidate or decline an offer to take a big order based on intuition. While such actions seemed irrational or counter-intuitive, the entrepreneurs made sense of such actions by projecting a future in which they had identified the right candidates, avoided real losses, or found more lucrative contracts that would better suit their businesses.

For instance, citing celestial inspiration, Fred told us about how, all of a sudden, he received a strong impression that it was necessary to collect the phone numbers and postal codes of their customers. "I didn't really know why, just felt like that was what I absolutely needed to do starting right now. So I did.” This decision turned out to be very important because, not long after, the decision was taken to close one of the stores. The collected information revealed that the majority of the customers lived in an area that could be served by their other store. As Fred noted:

"Right away I could see by looking at the postal codes that more than a half of my South store customers were coming from the North side of town or from the outskirts of town. I was pretty much guaranteed that at least half of the sales [of the South store] would go to the other store."

Making sense of this situation, Fred invoked past, present and future.

In this case, when the entrepreneur is trying to make sense of the situation triggered by the necessity to close one of the stores, he draws on all three temporal dimensions. Sensemaking in the present, he retrospectively explains why he received the inspiration to record the postal codes, and constructs a future in which more sales go to the other store. This future sense, however, is assured because of the epistemic sureness gathered from the inspiration he received. Believing that such inspirations are likely to continue into the future, his decision to base actions on these assessments is given additional certainty. A magical realist cognition in the present supports future-oriented sensemaking. 
Another feature of obtaining answers involved entrepreneurs' active seeking of inspiration in their daily business activities through prayer and meditation. Yves told us how he searches for answers to particularly tough questions he encounters in his business:

"I stand in the shower in the morning, and I'm having my shower and I pray. And I pray to give me the guidance to sort this out, show me what I've missed, and by the time I have done my shower, I have three more avenues to go look for. But when I got in it, I had none. So the water is not that smart. It's not the water. And that's what happens. It happens every single time.

The epistemic certainty of the "shower method" ("it happens every time") belies a magical realist orientation, which Yves himself tacitly admits ("the water is not that smart"). Actively seeking inspiration allows the entrepreneurs to obtain the answers they need and construct the future they want. Sometimes the inspiration is taken so seriously as to become a guiding principle for the business as a whole.

Supernatural Help. Entrepreneurs often noted being led or helped by a supernatural being or entity, sometimes mixed this idea with the notion of fate. For instance, they discussed how they were repetitively driven towards a certain decision, for example in the development of their business, or how they were assured in the appropriateness of their decision to bring results. They noted being selected or chosen to have certain successes, or about how certain events or business decisions responded to their prayers or were due to "star alignment."

Many entrepreneurs told us that God or the Universe helps them whenever they are looking to obtain answers to decisions or going through rough times. Their sense that this would happen in the future was based on past experiences where they had felt such aid. The belief in supernatural support is projected forward, with the expectation that their business will be blessed with success.

Adam told a story about a business decision based on his employee's dream. They were faced with the need for a solution to secure an important order, an order important to the business but also personally to the entrepreneur because of an emotional connection to that 
particular job. An employee of the company, not particularly religious or spiritual, had been frustrated at the lack of a solution, despite Adam's statement that he believed the employee could find the answer. The next morning the employee called the boss and told him that he saw the solution in his dream:

"He called me the next morning. He had a dream that night. This big, three-hundred pound Harley guy had a dream... and told me all about it with almost tears in his eyes."

The employee subsequently executed the solution in exactly the way he saw it in the dream, and company's future achievement of the order was seen in the light of this insight.

When asked about what can raise her odds for success, Claire, the young founder and CEO of a booming trendy company told us about her beliefs in the help of the Universe:

"[I have] this reminder...periodically, which is 'tell the Universe what you want'.... You have to actually know what you want, then you have to put it out into the world. ...what I'm saying and what I'm telling the Universe, except I'm telling the Universe that I'm "too this" to succeed at that, than I probably am. I'm telling the universe that I intend to succeed at something, or I intend to accomplish something, then, there is a positive effect there...That idea of putting ideas out there to the Universe, and being prolific about it, and creating as many connection points around that, to me that is increasing my statistical odds."

Claire saw the Universe as helping in mysterious ways, as for example, in meeting the right people at the right time. Strangers that Claire serendipitously met were instrumental in her winning a prestigious business case competition, and in securing the first and crucially important contract without which the company would not have started. Claire believes in having had supernatural help, and bases her future-oriented sensemaking on assurance that supernatural help will continue to appear and put things in place for her.

As a cognitive-epistemic dimension, obtaining the answers is an important part of entrepreneurs' magical realist orientations. Entrepreneurs operate in an uncertain environment full of novelty, information overload, and stress. In a world of decisions under time pressure, and susceptibility to cognitive errors and biases, a magical realist orientation allows entrepreneurs to overcome paralysis of action in the face of risk and uncertainty and find the 
solutions despite all the challenges, or at least keep looking with the hope than a solution will appear.

\section{Pragmatic-Motivational Orientation/Finding One's Path}

We term "finding one's path" the action component of magical realism, a practiceoriented tendency to engage in action or to see oneself as a vehicle for larger forces. Our respondents commonly expressed the need to find their own path in their narratives. Finding one's path depicts an entrepreneur guided to start and continue a business as an instrument or a vehicle for a higher force. Rather than a single step, it is an ongoing process involving projecting oneself into the future. For example, very wealthy entrepreneur, Adam, who built a large business operation over the course of his life, noted:

"I really believe the Lord has selected this family to have this wealth for a reason and that my goal over the next 20 years in my life, if I'm fortunate to stay here in another twenty, is to discover what that is."

Because it is an ongoing process, a big element of finding your path has to do with creation of a vision and construction of a positive future for yourself and for others. Both intuition and helping people continue to play a role in this process.

Intuition. Our respondents often spoke about starting their businesses based on intuition, often fueled by a prompting or a divine guidance to take up a particular business activity or commercial property. Such intuition triggered the determination to begin and continue a business, and respondents attributed more importance to this than to market research or supply and demand analysis. Many of our entrepreneurs began without a business plan, using intuition to construct their future and view themselves as successful business people. Future-oriented sensemaking was based on the intuition at the moment or in the past, but very tangible results, such as possession of a successful business, or financial freedom, were projected to the future. Such a mixture of spiritual elements as externally driven intuition with real matters is symptomatic of magical realist perception. 
The intuition that entrepreneurs talked about was usually externally driven in the form of prompting or guidance. For example, Nick, an entrepreneur working in the professional services of the internet industry said: "I have had transcendent experiences. Where I feel very strongly [...] I did have a very strong premonition or even an admonition to start a business."

Gavin, a very successful video games company founder, shares how he used intuition to start his business, part of which was the decision to pay a large sum of money to a key partner:

But I had no doubt at that moment that it was the right thing. Even though, I'm paranoid about, "Oh, God. I'm going to be spending a lot of money in sending it to a bad partner." ...But I'm just...calm inside because instinctually, I knew, it was the right move to make. And I think the biggest thing there is just being calm about it.... just intuitively felt like it is the right thing...I never felt conflicted about it.

Yves reflecting back on his experiences shared:

"When I started [this business], I wasn't Christian. But I look back and I still believe it was God's guidance. I've always believed in God, but not a Christian, but believed in Him. But if you look at all the facts, how everything played out, there is no way I could have done all that myself."

Starting a business through a divine communication is an important part of the story that the entrepreneurs told us. Often such communications appeared with little or no prior experience. Unable to draw on past successes with building and running a business, they draw on premonitions to engage in future-oriented sensemaking and construct a future vision of success.

Basing their actions on supernatural inspirations allowed entrepreneurs to imagine positive futures and to continue working to build their business in the face of challenges. They felt determination, bolstered by a sense of divine guidance, enabling them to leap into an unknown future.

Helping People. Specifically within the action orientation linked to magical realism, we noted an emphasis on helping people. Either through charity or CSR initiatives, or simply helping those in proximity, the entrepreneurs described a spiritual connection to helping others, and saw their business activities as a means to help others. In contrast to the ostensive economic 
rationality of their businesses, respondents reported that helping was central to their operations' success, and a path to prosperity. They mentioned helping, specifically, as a source of good luck, or other blessings. As a source for future-oriented sensemaking, this link between helping and success was a constant feature of respondents' narratives.

Some entrepreneurs felt very strongly that the business' purpose was to help or bless the lives of others, and some described this aspect as being an instrument of supernatural powers. For example, Vincent discussed about his choice of a particular business activity:

"I believe, that my purpose is to use the talents that God has given me to build businesses that have some type of a social impact. To be quite candid between you and I, if what I was doing was solely about the money, there's a lot of other things that I'd be focusing my time on. While [...] that's one of the motivations for going into business for yourself for becoming an entrepreneur, I would say, an even bigger motivation for me that goes back to my spiritual belief is I want to be able to kind of help people have better lives. I want to feel like that the world is a better place because I did my part."

In Vincent's statement, the future is constructed through referring the past, in which he has been given talents, and the present, which is the outcome of these talents. He considers himself as having receive a divine gift, with the purpose of helping people, which requires him to find the right path. The entrepreneur, an MBA alumnus from a prestigious school, had started a social business in Africa rather than follow a more lucrative career elsewhere.

Our respondents sometimes used supernatural intervention to explain their position and/or wealth, leading to a sense that they should help people in the present and in the future. They described their actions toward others as blessings and took joy in seeing the results of their work. Feeling that their past was blessed, they felt motivated to project a feeling of giving back in the future, motivating them to continue the business and not give up or retire early.

Being supernaturally inspired, and feeling oneself to be a vehicle for wider powers, are themes common in magical realist fiction, which abounds with instances of finding a magical path. The importance of intuition in the novels of Allende or Esquivel, for example, see protagonists acting on intuition with scientific accuracy despite the seeming impossibility, 
based on the spirit of a dead relative. Magical realism often deals in the law of attraction, relevant to the theme of helping people, and engaging in symbolic actions that have real consequences. Gestures with special meanings, that invoke spirits, are common fare in this kind of storytelling.

The theme of finding your path reflects a pragmatic-motivational mechanism of entrepreneurial activity. This pragmatic-motivational impulse goes beyond the rational maximization of personal utility and material rewards, emphasizing the symbolic nature of traveler images. As travelers who follow higher powers that unlock possibilities, entrepreneurial actions take on meaning beyond wealth creation. Such narratives allow entrepreneurs to feel that they have fulfilled a higher purpose. Providing a continuity in their identity, the pragmatic-motivational impulse draws on past and present successes to define a future. Feeling that their journey occurs as a junction of time past and time future enables entrepreneurs to face risk and uncertainty.

Insert Table 3 about here

\section{Discussion}

This paper develops the idea of magical realism to explain the critical role that spirituality plays in entrepreneurial cognition. Our interest was in understanding the unique view of reality that enables entrepreneurs to persist in the face of high uncertainty and risk. This world-view, described by the multi-dimensional concept of magical realism, is demonstrated by the answers that our respondents offer to the fundamental concerns of entrepreneurship - 'what is happening out there?', 'how will it affect me?' and 'what am I to do about it?'

Our respondents treated such questions, beyond the specific acts of entrepreneurship, as existential questions about the meaning of life, and responded with spiritually oriented answers, whether deriving from a specific religion or not. As we demonstrate in Table 2 , the 
first question was understood as referring to each respondent's cosmology - i.e. 'what is your understanding of the nature of the universe?' or more philosophically 'what is the nature of reality?' The second question was interpreted as referring to the role of the individual in that cosmology - i.e. 'given the nature of the universe, what is my role in it to be?' And the last question was processed as a fundamental question of agency - i.e. 'given the nature of the universe and my assumed role in it, how should I act?'

Insert Table 2 about here

Through our analysis of the narratives of the entrepreneurs, we uncovered thematic answers to the three existential questions. The first theme - being at peace - describes a shared cognitive assumption amongst our entrepreneurs of a cosmology of individual transcendence, in which the respondent sees a universe that is both larger and more mysterious than individual cognition can comprehend. Critically, the respondents not only accept their lack of agency in this cosmology, they find solace in the size and complexity of the universe that opens the opportunity of equifinality, or multiple paths to success. This sensemaking strategy seeks cosmological support for future uncertainly by allowing acceptance of one's limits within a larger order.

We use the term affective-attitudinal to describe this cognitive orientation, which grants the entrepreneur a degree of calm reflexivity and peace in the attitude that, despite the inherent risk in a turbulent world, their ultimate success or failure is beyond the agency of a single individual. Our entrepreneurs manage risk and uncertainty, thus, through a form of acceptance that willfully acknowledges that the universe is a large and mysterious environment with multiple means of both failure and success. 
The second theme - obtaining the answers - pertains to understanding one's role or place in the universe, giving a sense of self-certainty despite the uncertainty of the universe. The critical existential question here is premised on identity - 'who am I' - and belonging 'how do I fit', 'what is my role or purpose in the cosmology I know'. We use the term cognitiveepistemological here to capture the thematic understanding, shared by our respondents, that despite the complex mystery and apparent ambiguity of the universe, the transcendent individual can gain insight into the order of the world and the role prescribed for their success. This insight is perhaps best illustrated by Weber's (1985) observation of Protestant belief in certainty of salvation through hard work and prosperity, a formula that articulates both a cosmology and the transcendent role of the individual in it.

The third theme - finding one's path - offers a pragmatic-motivational dimension that secures individual agency through a magical realist belief in action in the face of a complex world. Despite an underlying attitude of fatalism, as described above, the individual entrepreneur locates him/herself in the cosmology and follows the "path" to success with perseverance. The pragmatic-motivational aspect of magical realism provides both the motivation to act and the willpower to continue - it is the ideological fortress used to overcome naysayers, and the risk and high probability of failure.

The three themes each contribute to a type of entrepreneurial cognition that gives nascent entrepreneurs a sense of confidence, motivation and agency in the absence of prior experience. Each cognitive orientation describes a degree of individual agency that is, somewhat paradoxically, embedded in a cosmology of fatalism. The entrepreneur accepts a universe replete with transcendent forces, but gains focus and direction by envisioning a path that can be realized by individual belief and effort. The collective cognitive orientation is magical inasmuch as it involves a cluster of beliefs that maintain individual focus and motivation by transmuting human agency from an instrumental-rational focus to one of 
alignment with a wider cosmological belief system. The model of entrepreneurial coping that emerges from this study is presented schematically in Figure 2.

Insert Figure 2 about here

We describe as magical realism the complex of these three cognitive orientations whose interrelation offers a spiritual engagement with the world that supports entrepreneurial cognition. This concept builds on related terms used to describe the role of spirituality in commerce, for instance, Ashforth and Pratt's (2003) “institutionalized spirituality”, which describe how organizations such as Amway or Disney adopt secularized forms of spirituality to develop strong organizational cultures. Similarly, Ashforth and Vaidyanath (2002) term "secular religion" the phenomenon of infusing profit-oriented rational organizations with meaning and value far beyond their technical purpose.

Both "institutionalized spirituality" and "secular religion" describe the counter-intuitive combination of empirical realism with spirituality that is of interest here. Magical realism contributes to this conceptualization because it effectively captures the balanced hybridization of empirical reality and wishful fantasizing that appears to define the unique cognition of entrepreneurs, particularly with reference to future-oriented sensemaking. Magical realism, in the context of entrepreneurial cognition, involves a category of sensemaking in which scientific and magical cosmologies usefully co-exist.

\section{Conclusion}

Our central research question asked how entrepreneurs draw upon magical thinking to support future-oriented sensemaking, leading us to draw upon the unifying concept of "magical realism" to explain entrepreneurs' orientation towards an uncertain future. We note that magical realist thinking supports entrepreneurs' attempts to mitigate risk and motivate action in the face 
of uncertainty. Through magical realism, entrepreneurs generate confidence in their actions and perceive themselves as playing a significant role in wider cosmological systems. Entrepreneurs adopt a magical realist orientation, not as a rejection of economic rationality, but because their lack of prior history and experience does not provide them with the information or resources to justify their behaviour. A spiritual orientation, by contrast, offers a supporting belief system an ideological fortress (Pratt, 2000) - within which they can justify their behaviour, a distinct identity or role within that system to motivate their behaviour, and a roadmap that offers a route to success. To construct a positive future, nascent entrepreneurs can thus draw on a powerful cognitive and spiritual orientation in lieu of past practices and successes or rhetorical uses of established technical competence and expertise (Gephart et al., 2010)

Our paper contributes to better understanding how entrepreneurs navigate risk and uncertainty in their everyday experience. While we know that future-oriented sensemaking is critical in entrepreneurial contexts (Cornelissen \& Clarke, 2010), focusing on how spirituality supports such sensemaking informs the "cosmological" aspect of sensemaking famously invoked by Weick (1993), but which has received scant development. The magical realism of entrepreneurs supports an "enchanted" worldview (Suddaby et al., 2017), in which structural constraints take back stage and possibilities remain open. Consistent with our characterization of magical realism, however, entrepreneurs' magical views do not fully abandon engagement in the 'real' world. Rather, pragmatic decisions are grounded on these views, which lead to concrete action plans. The construct of magical realism, thus, usefully bridges the tension between two somewhat incompatible value systems in which the sovereignty of interpretation is often contested (Boltanski \& Thevenot, 2006).

The mechanism of coping with risk described in the paper and set out in Figure 2 effectively illustrates a model of reflexivity in which our entrepreneurs have devised a system of reflection through which they strive to capture the cosmological system that they inhabit, 
their role in it and their opportunities for expressing agency. The cognitive-epistemic aspect of magical realism support a belief system in which the horizon for success remains open, while the affective-attitudinal aspects supports optimism and a sense of peace in the face of uncertainty. Finally, the pragmatic-motivational aspect marks a willingness to commit to the unknown while trusting one's intuition, and to feel that one's entrepreneurship constitutes a form of service to a higher cause.

The discussion of magical realism in the context of entrepreneurship raises new questions. For instance, notions of past- versus future- oriented sensemaking in the current literature (e.g. Gephart et al., 2010; Gioia \& Mehra, 1996) work around dominant linear conceptions of time that may differ among those adopting magical realist orientations. Because the latter tend to view their project transcendentally, divisions between past and future may fuse into an immanent sense of the present, bracketing and problematizing conventional, linear time. We theorize future-oriented sensemaking based on the presumption of the "future" as what is to come. Given that subjective experiences of time and the timing of action are not necessarily aligned with "clock time" (Cunha, 2008), however, cosmological views of one's actions may sideline this conventional account of time. Future research, therefore, should explore how sensemaking processes not only involve magical thinking, but also can be shaped by how time is experienced subjectively.

Additionally, while we discuss how entrepreneurs with little prior experience embed their sense of agency in a broader cosmological belief system, how this spiritual agency functions under conditions of failure is less understood. Past studies on sensemaking in the context of past failure (e.g. Cardon et al., 2011) could thus be complemented by examining the relevance of spirituality in the experience of failure. How does magical realism affect entrepreneurship when cosmology events disrupt adherence to spiritual belief systems? Is a magical view of the world lost in such situations, or does it build resilience to failure? Relatedly, 
if success or failure can reinforce or erode magical thinking, what are the feedback processes by which these worldly events shape transcendental orientations and vice-versa? Prior research suggests that individuals rely on external cosmologies in the face of risk and uncertainty. Does realized success encourage entrepreneurs to adopt increasingly rational explanations over time? In short, both success and failure are likely to unleash dynamics between action and belief that require longitudinal and process research to uncover, and such research is an important agenda for developing the magical realism construct.

Finally, our study used a sample of both religious and non-religious entrepreneurs, and we developed the concept of magical realism to be an umbrella term not specific to any given religious context. In this framing we follow Cunha's (2006) conceptual distinction between religion and spirituality, characterizing our own approach as focusing on spirituality. Yet, it is likely that magical realism will manifest itself in different ways across religious (and nonreligious) traditions, drawing upon distinct resources according to cosmological belief systems. Thus, future research should examine more specifically how particular background belief systems can affect the contours and expression of magical realist beliefs and their effects on sensemaking processes.

Our wish is that this study will help advance new theory, research and practice on processes of magical thinking in entrepreneurial sensemaking. By establishing this construct empirically, inductively outlining its sub-components, and theorizing these within an integrative framework, we foresee that this new direction of research will encourage more innovative thinking about how entrepreneurs interpret their external reality. 


\section{References}

Allende, I. (1991). The Shaman and the Infidel. New Perspectives Quarterly. 8, 1: 54.

Atkinson, R. (1998). The life story interview. Sage.

Ashforth, B.E., \& Pratt, M.G. (2003). Institutionalized spirituality. Handbook of Workplace Spirituality and Organizational erformance, 93-107.

Ashforth, B.E. \& Vaidyanath, D. (2012). Work organizations as secular religions. Journal of Management Inquiry, 11(4): 359-370.

Ball S.B., Bazerman M. H., Carroll J. S. (1991) An evaluation of learning in the bilateral winner's curse. Organizational Behavior Human Decision Processes, 48:1-22

Balog, A.M., Baker, L.T., \& Walker, A.G. (2014). Religiosity and spirituality in entrepreneurship: A review and research agenda. Journal of Management, Spirituality and Religion, 11(2), 159-186.

Baltar, F., \& Brunet, I. (2012). Social research 2.0: virtual snowball sampling method using Facebook. Internet Iesearch, 22(1), 57-74.

Baron, R.A. (2004). The cognitive perspective: a valuable tool for answering entrepreneurship's basic "why” questions. Journal of Business Venturing, 19(2), 221-239.

Baron, R.A., \& Markman, G.D. (1999). Cognitive mechanisms: Potential differences between entrepreneurs and non-entrepreneurs. Frontiers of Entrepreneurship Research, 123137.

Bergson, H. (2002). Henri Bergson: Key Writings. A\&C Black.

Boltanski, L., \& Thévenot, L. (2006). On Justification: Economies of Worth. Princeton: Princeton University Press.

Brown, A.D., Stacey, P., \& Nandhakumar, J. (2008). Making sense of sensemaking narratives. Human Relations, 61(8), 1035-1062.

Brüderl, J., Preisendörfer, P., \& Ziegler, R. (1992). Survival chances of newly founded business organizations. American Sociological Review, 227-242.

Busenitz, L.W., \& Barney, J.B. (1997). Differences between entrepreneurs and managers in large organizations: Biases and heuristics in strategic decision-making. Journal of Business Venturing, 12(1), 9-30.

Busenitz, L.W., \& Lau, C.M. (1996). A cross-cultural cognitive model of new venture creation. Entrepreneurship: Theory and Practice, 20(4), 25-40.

Cardon, M.S., Stevens, C.E., \& Potter, D.R. (2011). Misfortunes or mistakes? Cultural sensemaking of entrepreneurial failure. Journal of Business Venturing, 26(1), 79-92. 
Carpentier, A. (1949). On the marvelous real in America. In Zamora, L.P., \& Faris, W.B. (Eds.) (1995). Magical Realism: Theory, History, Community. Duke University Press.

Clandinin, J. (2013). Engaging in Narrative Inquiry. Routledge.

Colville, I., \& Pye, A. (2010). A sensemaking perspective on network pictures. Industrial Marketing Management, 39(3), 372-380.

Colville, I., Pye, A., \& Brown, A.D. (2015). Sensemaking processes and Weickarious learning. Management Learning, 47(1), 3-13.

Cornelissen, J.P., \& Clarke, J.S. (2010). Imagining and rationalizing opportunities: inductive reasoning and the creation and justification of new ventures. Academy of Management Review, 35(4), 539-557.

Cunha, M.P. (2006). Organizational spiritualities: An ideology-based typology. Business \& Society, 45(2), 211-234.

Cunha, M.P. (2008): The organizing of rhythm, the rhythm of organizing. In: Time in organizational research: Approaches and methods. R.A. Roe, M.J. Waller and S.R. Clegg (Eds.), 220-237. Routledge, London.

Dana, L.P. (2009). Religion as an explanatory variable for entrepreneurship. The international journal of entrepreneurship and innovation, 10(2), 87-99.

Dodd, S.D., \& Gotsis, G. (2007). The interrelationships between entrepreneurship and religion. The International Journal of Entrepreneurship and Innovation, 8(2), 93-104.

Dodd, S.D., \& Seaman, P.T. (1998). Religion and enterprise: An introductory exploration. Entrepreneurship Theory and Practice, 23(1), 71-86.

Dorado, S. (2005). Institutional entrepreneurship, partaking, and convening. Organization Studies, 26(3), 385-414.

Dougherty, K.D., Griebel, J., Neubert, M.J., \& Park, J.Z. (2013). A religious profile of American entrepreneurs. Journal for the Scientific Study of Religion, 52(2), 401-409.

Economy Rankings (n.d.). Retrieved December 15, 2017, from http://www.doingbusiness.org/rankings

Eisenhardt, K.M. (1989). Building theories from case study research. Academy of Management Review, 14(4), 532-550.

Faris, W.B. (2004). Ordinary enchantments: Magical realism and the remystification of narrative. Vanderbilt University Press.

Fernando, M., \& Jackson, B. (2006). The influence of religion-based workplace spirituality on business leaders' decision-making: An inter-faith study. Journal of Management \& Organization, 12(1), 23-39. 
Fisher, C.D. (1986). Organizational socialization: An integrative review. Research in Personnel and Human Resources Management, 4(1), 101-145. 192.

Flores, A. (1955). Magical realism in Spanish American fiction. Hispania, 38(2), 187-

Gatewood, E.J., Shaver, K.G., Powers, J.B., \& Gartner, W.B. (2002). Entrepreneurial expectancy, task effort, and performance. Entrepreneurship Theory and Practice, 27(2), 187206.

Gephart, R.P., Topal, C., \& Zhang, Z. (2010). Future-oriented sensemaking: Temporalities and institutional legitimation. Process, Sensemaking, and Organizing, 275-312.

Gioia, D.A., \& Mehra, A. (1996). Sensemaking in organizations. The Academy of Management Review, 21(4), 1226.

Gioia, D.A., Thomas, J.B., Clark, S.M., \& Chittipeddi, K. (1994). Symbolism and strategic change in academia: The dynamics of sensemaking and influence. Organization Science, 5(3), 363-383.

Glaser, B., \& Strauss, A. (1967). Grounded theory: The discovery of grounded theory. Sociology, 12, 27-49.

Godwin, J.L., Neck, C.P., \& D’Intino, R.S. (2016). Self-leadership, spirituality, and entrepreneur performance: A conceptual model. Journal of Management, Spirituality \& Religion, 13(1), 64-78.

Grégoire, D.A., Corbett, A.C., \& McMullen, J.S. (2011). The cognitive perspective in entrepreneurship: An agenda for future research. Journal of Management Studies, 48(6), $1443-1477$.

Griffin, D.W., \& Ross, L. (1991). Subjective construal, social inference, and human misunderstanding. Advances in Experimental Social Psychology, 24, 319-359.

Hayward, M.L., Shepherd, D.A., \& Griffin, D. (2006). A hubris theory of entrepreneurship. Management Science, 52(2), 160-172.

Heidegger, M. (1962). Being and Time. New York: Harper.

Hicks, D.A. (2003). Religion and the Workplace: Pluralism, spirituality, leadership. Cambridge University Press.

Hill, R.C., \& Levenhagen, M. (1995). Metaphors and mental models: Sensemaking and sensegiving in innovative and entrepreneurial activities. Journal of Management, 21(6), 1057-1074.

Holt, R., \& Cornelissen, J. (2014). Sensemaking revisited. Management Learning, 45(5), 525-539. 
Hoyer, P., \& Steyaert, C. (2015). Narrative identity construction in times of career change: Taking note of unconscious desires. Human Relations, 68(12), 1837-1863.

Hytti, U. (2005). New meanings for entrepreneurs: from risk-taking heroes to safeseeking professionals. Journal of Organizational Change Management, 18(6), 594-611.

Introna, L.D. (2018). On the making of sense in sensemaking: Decentred sensemaking in the meshwork of life. Organization Studies, 0170840618765579.

Johansson, A.W. (2004). Narrating the entrepreneur. International Small Business Journal, 22(3), 273-293.

Judge, W.Q., \& Douglas, T.J. (2013). Entrepreneurship as a leap of faith. Journal of Management, Spirituality \& Religion, 10(1), 37-65.

Guiette, A., \& Vandenbempt, K. (2015). Learning in times of dynamic complexity through balancing phenomenal qualities of sensemaking. Management Learning, 47(1), 8399.

Karakas, F. (2010). Spirituality and performance in organizations: A literature review. Journal of Business Ethics, 94(1), 89-106.

Kauanui, S.K., Thomas, K.D., Rubens, A., \& Sherman, C.L. (2010). Entrepreneurship and spirituality: A comparative analysis of entrepreneurs' motivation. Journal of Small Business \& Entrepreneurship, 23(4), 621-635.

Keinan, G. (1994). Effects of stress and tolerance of ambiguity on magical thinking. Journal of Personality and Social Psychology, 67(1): 48-55.

Konlechner, S., Latzke, M., Güttel, W.H., \& Höfferer, E. (2018). Prospective sensemaking, frames and planned change interventions: A comparison of change trajectories in two hospital units. Human Relations.

Krueger, N.F. (2003). The Cognitive Psychology of Entrepreneurship. Pp 105-140 in Acs, Z.J. \& Audretsch, D.B. (Eds.), Handbook of Entrepreneurship Research, London: UK: Kluwer Law International.

Kruger, J., \& Dunning, D. (1999). Unskilled and unaware of it: how difficulties in recognizing one's own incompetence lead to inflated self-assessments. Journal of Personality and Social Psychology, 77(6), 1121.

La Pira, F., \& Gillin, M. (2006). Non-local intuition and the performance of serial entrepreneurs. International Journal of Entrepreneurship and Small Business, 3(1), 17-35.

Lips-Wiersma, M. (2002). The influence of spiritual "meaning-making" on career behavior. Journal of Management Development, 21(7), 497-520.

Lipshitz, R., Ron, N., \& Popper, M. (2004). Retrospective sensemaking and foresight: studying the past to prepare for the future. Managing the Future, 98. 
Maitlis, S. (2012). Narrative analysis. In G. Symon \& C. M. Cassell (Eds.), Qualitative organizational research: Core methods and key challenges (pp. 492-511). London: SAGE Publications.

Maitlis, S., \& Christianson, M. (2014). Sensemaking in organizations: Taking stock and moving forward. The Academy of Management Annals, 8(1), 57-125.

Mauksch, S. (2017). Managing the dance of enchantment: An ethnography of social entrepreneurship events. Organization, 24(2), 133-153.

McKee, M.C., Mills, J.H., \& Driscoll, C. (2008). Making sense of workplace spirituality: Towards a new methodology. Journal of Management, Spirituality \& Religion, 5(2), 190-210.

McKelvie, A., Haynie J.M \& Gustavsson, V. (2011). Unpacking the uncertainty construct: Implications for entrepreneurial action. Journal of Business Venturing 26 273-292.

McLean, K.C., \& Pasupathi, M. (2011). Old, new, borrowed, blue? The emergence and retention of personal meaning in autobiographical storytelling. Journal of Personality, 79(1), 135-164.

McMullen, J.S. \& Shepherd, D.A. (2006) Entrepreneurial action and the role of uncertainty in the theory of the Entrepreneur. Academy of Management Journal, 31(1), 132152.

Miles, M.B., \& Huberman, A. M. (1994). Qualitative data analysis: An expanded sourcebook. Sage.

Milliken, F.J. (1987). Three types of perceived uncertainty about the environment: State, effect, and response uncertainty. Academy of Management Review, 12(1), 133-143.

Mitchell, R.K., Smith, B., Seawright, K.W., \& Morse, E.A. (2000). Cross-cultural cognitions and the venture creation decision. Academy of Management Journal, 43(5), 974993.

Moore D.M., Kim T.G. (2003) Myopic social prediction and the solo comparison effect. Journal of Personality and Social Psychology, 85:1121-1135

Moore, L. and Koning, J. (2015) Intersubjective identity work and sensemaking of adult learners on a postgraduate coaching course: Finding the balance in a world of dynamic complexity, Management Learning, 47(1), pp. 28- 44.

Neubert, M.J. (2013). Entrepreneurs Feet Closer to God Than the Rest of Us Do. Harvard Business Review.

Neubert, M.J., Bradley, S.W., Ardianti, R., \& Simiyu, E.M. (2017). The role of spiritual capital in innovation and performance: Evidence from developing economies. Entrepreneurship Theory and Practice, 41(4), 621-640. 
Orton, J.D. \& O’Grady, K.A. (2016). Cosmology episodes: a Reconceptualization. Journal of Management, Spirituality \& Religion, 13(3): 226-245.

Patton, M.Q. (2014). Qualitative Research \& Evaluation Methods. Sage.

Pratt, M.G. (2000). Building an ideological fortress: The role of spirituality, encapsulation and sensemaking. Studies in Cultures, Organizations and Societies, 6(1), 35-69.

Rae, D. (2000). Understanding entrepreneurial learning: a question of how? International Journal of Entrepreneurial Behavior \& Research, 6(3), 145-159.

Rae, D., \& Carswell, M. (2001). Towards a conceptual understanding of entrepreneurial learning. Journal of Small Business and Enterprise Development, 8(2), 150158.

Rasmussen, E.S., Koed Madsen, T., \& Evangelista, F. (2001). The founding of the born global company in Denmark and Australia: Sensemaking and networking. Asia Pacific Journal of Marketing and Logistics, 13(3), 75-107.

Rego, A., \& Cunha, M.P (2008). Workplace spirituality and organizational commitment: an empirical study. Journal of Organizational Change Management, 21(1), 5375 .

Riessman, C.K. (1993). Narrative analysis (Vol. 30). Sage.

Rouleau, L., \& Balogun, J. (2011). Middle managers, strategic sensemaking, and discursive competence. Journal of Management Studies, 48(5), 953-983.

Sandberg, J., \& Tsoukas, H. (2015). Making sense of the sensemaking perspective: Its constituents, limitations, and opportunities for further development. Journal of Organizational Behavior, 36(S1), S6-S32.

Schwandt, T.A. (1994). Constructivist, interpretivist approaches to human inquiry. Handbook of Qualitative Research, 1, 118-137.

Stigliani, I., \& Ravasi, D. (2012). Organizing thoughts and connecting brains: Material practices and the transition from individual to group-level prospective sensemaking. Academy of Management Journal, 55(5), 1232-1259.

Suddaby, R., Ganzin, M., \& Minkus, A. (2017). Craft, magic and the re-enchantment of the world. European Management Journal, 35(3), 285-296.

von Gelderen, M., Frese, M., \& Thurik, R. (2000). Strategies, uncertainty and performance of small business startups. Small Business Economics, 15(3), 165-181. Paperbacks.

Weber, M. (1985). The protestant ethic and the spirit of capitalism. London: Unwin

Weick, K.E. (1993). The collapse of sensemaking in organizations: The Mann Gulch disaster. Administrative Science Quarterly, 628-652. 
Weick, K.E. (1995). Sensemaking in organizations (Vol. 3). Sage.

Wiebe, E. (2010). Temporal sensemaking: Managers' use of time to frame organizational change. Process, Sensemaking, \& Organizing, 213-241.

Zamora, L.P., \& Faris, W.B. (1995). Magical Realism: Theory, History, Community. Duke University Press. 


\section{Appendix}

Figure 1: Data Structure

\begin{tabular}{|l|c|c|}
\hline \multicolumn{1}{|c|}{ First-order Codes } & Second-order Codes & Aggregate Themes \\
\hline Obeying particular laws of life (karma) & Laws of life (karma) & \multirow{2}{*}{$\begin{array}{c}\text { Affective-Attitudinal } \\
\text { Being at peace }\end{array}$} \\
\cline { 1 - 1 } Living as you should & Doing the right thing & \\
\hline God's Care & Succumbing to God's (Universe's) will & D.
\end{tabular}

\begin{tabular}{|l|c|c|}
\hline Right thing to do & Inspiration & Cognitive-Epistemic \\
\cline { 1 - 1 } Revelation though thoughts & Obtaining the answers \\
\hline Hand of God or the Universe & Supernatural help & \\
\hline Divine intervention & \\
\hline
\end{tabular}

\begin{tabular}{|l|c|c|}
\hline Divine guidance & Intuition & Pragmatic-Motivational: \\
\cline { 1 - 1 } Driven to start a business & Finding one's path \\
\hline Instrument in the hands of God & Helping people & \\
\hline Blessings are for social impact & Ping \\
\hline
\end{tabular}


Table 1: Participant Description

\begin{tabular}{|c|c|c|c|c|c|c|}
\hline Pseudonym & Age & Gender & $\begin{array}{l}\text { Religious } \\
\text { adherence }\end{array}$ & \begin{tabular}{|l} 
Years in \\
business
\end{tabular} & Industry & $\begin{array}{c}\text { \# of } \\
\text { employees }\end{array}$ \\
\hline Adam & $55-59$ & $\mathrm{M}$ & Protestant & 35 & Construction & 280 \\
\hline Brandon & $55-59$ & $\mathrm{M}$ & Protestant & 29 & Retailing & 36 \\
\hline Charles & $40-44$ & $\mathrm{M}$ & Non-religious & 16 & Retailing & $>50$ \\
\hline David & $25-29$ & $\mathrm{M}$ & Non-religious & 5 & Software & 6 \\
\hline Eric & $30-34$ & $\mathrm{M}$ & Non-religious & 6 & IT & 12 \\
\hline Frank & $50-54$ & $\mathrm{M}$ & Non-religious & 15 & Professional Services & 5 \\
\hline Anna & $30-34$ & $\mathrm{~F}$ & Buddhist & 5 & Consumer Services & 6 \\
\hline George & $40-44$ & $\mathrm{M}$ & Protestant & 9 & Software & 6 \\
\hline Harry & $55-59$ & $\mathrm{M}$ & Protestant & 23 & Health Care Equipment \& Supplies & 150 \\
\hline Ian & $70-74$ & $\mathrm{M}$ & Protestant & 40 & Construction Materials & $>200$ \\
\hline James & $40-44$ & $\mathrm{M}$ & Protestant & 14 & Capital Markets & $>130$ \\
\hline Kevin & $35-39$ & $\mathrm{M}$ & Non-religious & 13 & Software & 21 \\
\hline Luke & $50-54$ & $\mathrm{M}$ & Protestant & 30 & Internet Software & 5 \\
\hline Mark & $35-39$ & $\mathrm{M}$ & Non-religious & 17 & Internet Software & 7 \\
\hline Nick & $45-49$ & $\mathrm{M}$ & Protestant & 8 & Professional Services & 12 \\
\hline Oliver & $35-39$ & $\mathrm{M}$ & Protestant & 12 & Specialty Retail & 300 \\
\hline Beth & $45-49$ & $\mathrm{~F}$ & Non-religious & 16 & Media & 14 \\
\hline Paul & $55-59$ & $\mathrm{M}$ & Protestant & 26 & Professional Services & 250 \\
\hline Quentin & $30-34$ & $\mathrm{M}$ & Muslim & 5 & Media & 14 \\
\hline Richard & $55-59$ & $\mathrm{M}$ & Non-religious & 12 & Consumer Services & $>100$ \\
\hline Scott & $40-44$ & $\mathrm{M}$ & Non-religious & 21 & Media & 22 \\
\hline Tyler & $40-44$ & $\mathrm{M}$ & Non-religious & 15 & Commercial Services \& Supplies & 9 \\
\hline Umberto & $40-44$ & $\mathrm{M}$ & Catholic & 6 & Media & 10 \\
\hline Vincent & $35-39$ & $\mathrm{M}$ & Protestant & 6 & Agriculture + Personal Products & 18 \\
\hline Winston & $35-39$ & $\mathrm{M}$ & Non-religious & 14 & Software & 35 \\
\hline Xavier & $30-34$ & $\mathrm{M}$ & Protestant & 5 & Media & 4 \\
\hline Yves & $50-54$ & $\mathrm{M}$ & Protestant & 22 & Consumer Services & 8 \\
\hline Claire & $35-39$ & $\mathrm{~F}$ & Non-religious & 5 & Media & 28 \\
\hline Zach & $35-39$ & $\mathrm{M}$ & Protestant & 14 & Construction & 40 \\
\hline Arthur & $30-34$ & $\mathrm{M}$ & Non-religious & 5 & Commercial Services \& Supplies & 11 \\
\hline Blake & $30-34$ & $\mathrm{M}$ & Non-religious & 7 & Health Care Services & 8 \\
\hline Calvin & $30-34$ & $\mathrm{M}$ & Non-religious & 5 & Software & 30 \\
\hline Daniel & $30-34$ & $\mathrm{M}$ & Non-religious & 5 & IT & 2 \\
\hline Edmund & $50-54$ & $\mathrm{M}$ & Protestant & 20 & IT & 45 \\
\hline Fred & $35-39$ & $\mathrm{M}$ & Protestant & 15 & Specialty Retail + Oil \& Gas & 25 \\
\hline Gavin & $40-44$ & $\mathrm{M}$ & Non-religious & 6 & Software & 38 \\
\hline Hugh & $45-49$ & $\mathrm{M}$ & Protestant & 11 & Software & 17 \\
\hline Ingmar & $30-34$ & $\bar{M}$ & Catholic & 6 & IT & 12 \\
\hline Jason & $70-74$ & $\mathrm{M}$ & Protestant & 40 & Medical Services & 32 \\
\hline Karl & $35-39$ & $\mathrm{M}$ & Non-religious & 13 & Internet Software & 3 \\
\hline
\end{tabular}


Table 2: Summary of the Attributes of Magical Realist Entrepreneurial Cognition

\begin{tabular}{|c|c|c|c|c|}
\hline $\begin{array}{l}\text { Critical } \\
\text { Questions of } \\
\text { Entrepreneurship }\end{array}$ & $\begin{array}{l}\text { Existential } \\
\text { Questions of } \\
\text { Entrepreneurship }\end{array}$ & $\begin{array}{l}\text { Cognitive } \\
\text { Orientation }\end{array}$ & $\begin{array}{l}\text { Component } \\
\text { Elements of } \\
\text { Cognitive } \\
\text { Orientation }\end{array}$ & $\begin{array}{l}\text { Entrepreneurial } \\
\text { Outcome }\end{array}$ \\
\hline \multirow[t]{2}{*}{$\begin{array}{l}\text { What is happening } \\
\text { out there? }\end{array}$} & \multirow[t]{2}{*}{$\begin{array}{l}\text { What is the nature } \\
\text { of the universe? }\end{array}$} & \multirow[t]{2}{*}{$\begin{array}{l}\text { Affective- } \\
\text { Attitudinal }\end{array}$} & $\begin{array}{l}\text { a. The laws } \\
\text { of life }\end{array}$ & \multirow{2}{*}{$\begin{array}{l}\text { Ideological } \\
\text { Fortress: } \\
\text { - ability to } \\
\text { overlook risk, } \\
\text { uncertainty and } \\
\text { lack of support }\end{array}$} \\
\hline & & & $\begin{array}{l}\text { b. Being at } \\
\text { peace }\end{array}$ & \\
\hline \multirow[t]{2}{*}{$\begin{array}{l}\text { How will it affect } \\
\text { me? }\end{array}$} & \multirow{2}{*}{$\begin{array}{l}\text { What is my } \\
\text { place/role in the } \\
\text { universe? }\end{array}$} & \multirow[t]{2}{*}{$\begin{array}{l}\text { Cognitive- } \\
\text { Epistemological }\end{array}$} & $\begin{array}{l}\text { a. Obtaining } \\
\text { the answers }\end{array}$ & \multirow{2}{*}{$\begin{array}{l}\text { Speculative } \\
\text { Spirituality: } \\
\text { - confidence } \\
\text { about one's role } \\
\text { independent of } \\
\text { outcome }\end{array}$} \\
\hline & & & $\begin{array}{l}\text { b. } \\
\text { Inspiration }\end{array}$ & \\
\hline \multirow[t]{2}{*}{$\begin{array}{l}\text { What am I going } \\
\text { to do about it? }\end{array}$} & \multirow[t]{2}{*}{$\begin{array}{l}\text { How should I } \\
\text { live/what is my } \\
\text { path? }\end{array}$} & \multirow[t]{2}{*}{$\begin{array}{l}\text { Pragmatic- } \\
\text { Motivational }\end{array}$} & $\begin{array}{l}\text { a. } \\
\text { Supernatural } \\
\text { help } \\
\end{array}$ & \multirow{2}{*}{$\begin{array}{l}\text { Motivation to } \\
\text { Act: } \\
\text { - willingness to } \\
\text { act in the absence } \\
\text { of perfect } \\
\text { information }\end{array}$} \\
\hline & & & $\begin{array}{l}\text { b. Finding } \\
\text { one's path }\end{array}$ & \\
\hline
\end{tabular}


Figure 2: Mechanism of coping

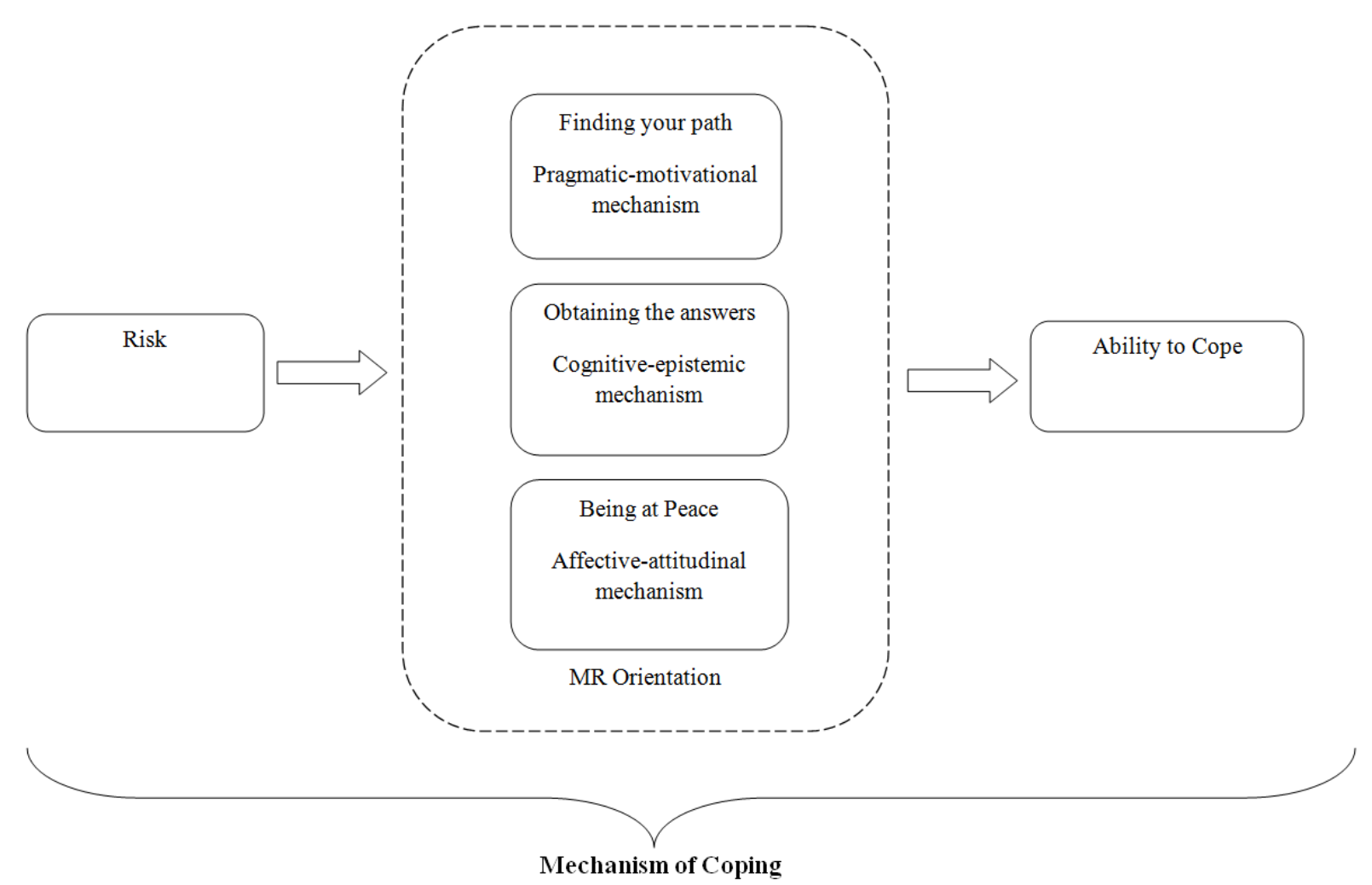


Table 3: Illustrative Verbatim for Key Themes 


\begin{tabular}{|c|c|}
\hline Theme & Examples from Data \\
\hline
\end{tabular}

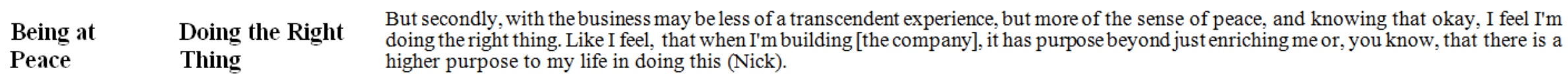

If I lose the whole thing, I can handle it because I know ..., I know in the end, this isn't my ultimate goal in life. My ultimate goal in life is to prove to God or to prove myself that I am worthy to return and live in heavens. So that faith gave me peace. I mean, it gave me assurance that all is well. It just doesn't matter. It's going to be okay (Jason).

The Laws of Life Another thing, you know, as far as prosperity and spiritual thing, we believe in the law of tithing. You know, as it says, "I'll open the (Karma) windows in heaven", and that doesn't necessarily mean financial growth... So like, I think, many times I was spared. I was spared costly accident, or costly damages that I didn't even recognize as I was blessed for paying my tithing, but I was blessed because I didn't have to suffer those losses (Jason).

I think [the Creator] set up laws and principles for us. If we follow them, then good will happen as a natural result of our actions. So, yeah, hard work, treating people fairly, doing what you said you are going to do, trying to put things right if you got them wrong, you know, coz people do make mistakes, be honest and straight forward with your clients (Richard).

Being good is very important(Brandon).

I have to believe in Karma in some way. Because we didn't... The minute he couldn't pay, we could've just said, you know, screw you. You call us when you can pay, but we didn't do that. I have very good personal relationships with a lot of my clients and I just always tried to be nice, I just believe in Karma. I don't burn any bridges and I'm always good to everyone that I do business with. Because it saved the business a few times now. So a customer complains about time entries. And you know also I don't care about the money that much. It's not that to me. It's more about making sure they're happy because they may end up in a situation where they end up meeting someone who ends up becoming like a multimillion dollar customer for us, right? I always have that in the back of my mind (Hugh)

\section{Obtaining the Inspiration Answers}

I just woke up and I have this solution in my mind and I have a specific feeling of what it was and I always go back to that feeling of what was sort of your original inspiration. And it was so many things at once as well. [...] it emerged as a feeling and it's that feeling I always chase; and I still chase it. [...] Then, it becomes part of a decision framework so if we want to add a new feature, or if people want to do some type of advertising with us, or they want to do some type of a business relationship, I always come back to what's the feeling that I want from this thing from the start (Xavier).

...Ibelieve it's divine guidance... where it's been like, you don't want to take this job. ... But I always wanna help people, right. So I'm like, I'm just gonna take the job and I'll work through it. One hundred percent of the time, those jobs come back to bite me, all the time. And one hundred percent of the time too, when I listened to that, what I call a prompting, the ones I have walked away from, I know the contractor that is on it, all the thoughts that I had of why should I walk away, have happened. I have walked away from jobs that would have been $\$ 150,000$ jobs and I thought that was really weird, why did I? ... Hundred percent of the time when I have not taken the job, there has been 
something better that has come, and then I was like okay, this would be why I had this feeling to walk or not put in the bid, and a better job comes around that is more suitable for the business. And that happens all the time. I can't even count on my hands how many times that has happened. And I have done it when we could really use the work. My foreman was like, "we need the work." ...You need to trust the feeling that you are having (Zach).

Supernatural

Help

Helping People

There is no reason in the world that it wouldn't run full throttle, and ran right over me. I mean, it just should have. But it died. Fired once, and died, and I just stood there realizing my life has just been spared miraculously. After trembling for a long time I got back in the cockpit, hit the starter and yet it roared to life without a question. So I know... I know, for some reason, my life was spared. I don't know why, but I know there was divine intervention that day (Jason).

I very much view, and I felt this multiple times, that the hand of God is in this business, and that, if the business is going to be successful, it's going to be successful not because of my own... certainly not only because of my own efforts. Ibelieve that I do need to play a part in that but it will be successful because God has quite a very active role in it, and so, whenever we have to make big decisions about the business or we're struggling, I would very much view God as kind of my business partner in this. And feel like, from time to time as needed, that he does play a very active role in how we kind of move forward the business (Vincent)

\section{Finding One's Intuition Path}

I think, intuition itself is like the risk thing. I think, the very nature of it is pointing in the direction that is the least risk (Xavier).

But it was that same year... so six months after I was accepted in the business [program at the university] is when I formed this corporation, and during that six-month period, from when I was accepted into business school, and decided to do this, you know, I had some very sure answers from, you know, my Heavenly Father that this is what I should do, that I should be in business and then I should start with own business (Adam).

One of them was, when we are running the software business, we would adopt a charity every year and then use it as a place to do a variety of R\&D, and give that to that association or that foundation as the beneficiary. And that gave us a chance to unify around the cause, we would spend time selecting it, we would also then be actively looking to use that as a moment to experiment with... with things, that other clients may be yet not prepared to pay for, but we would want to showcase as an example. And... so, that ends our corporal social responsibility was, that particular company, something we measure rather explicitly, but I came to realize as we were through that process, that in a business focused on information or on... ahm... professional services, often you are in the business of doing something, that is already trying to raise something to its highest and best use, that is a demonstrable example of the kinds of things that a CSR program singles out. So, it becomes an essence part of the mission (Edmund).

That to me is what [this business] is for. Does that make sense? That's important. So if [my business] wasn't here, I would not have been here to help her, wouldn't be here for the car, and wouldn't be here to put them back together again. As I spent two hours with her, talking to her: how are you doing? How was it at your dad's? What happened? I could not have [doing business] for two hours, but that's not what's important(Yves). 